American Journal of Applied Sciences 5 (9): 1257-1262, 2008

ISSN 1546-9239

(C) 2008 Science Publications

\title{
Ductility Performance of Hybrid Fibre Reinforced Concrete
}

\author{
${ }^{1}$ S. Eswari, ${ }^{2}$ P.N. Raghunath and ${ }^{2}$ K. Suguna \\ ${ }^{1}$ Department of Civil Engineering,Pondicherry Engineering College, Pondicherry-605 014, India \\ ${ }^{2}$ Department of Civil and Structural Engineering, \\ Annamalai University, Annamalainagar-608 002, India
}

\begin{abstract}
This study presents a study on the ductility performance of hybrid fibre reinforced concrete. The influence of fibre content on the ductility performance of hybrid fibre reinforced concrete specimens having different fibre volume fractions was investigated. The parameters of investigation included modulus of rupture, ultimate load, service load, ultimate and service load deflection, crack width, energy ductility and deflection ductility. A total of 27 specimens, $100 \times 100 \times 500 \mathrm{~mm}$, were tested to study the above parameters. The specimens incorporated 0.0 to $2.0 \%$ volume fraction of polyolefin and steel fibres in different proportions. The ductility performance of hybrid fibre reinforced concrete specimens was compared with that of plain concrete. The test results show that addition of $2.0 \%$ by volume of hybrid fibres improves the ductility performance appreciably. An adaptive NeuroFuzzy based model has been proposed to predict the ductility performance characteristics. A reasonably close agreement has been obtained between the experimental and predicted results.
\end{abstract}

Key words: ANFIS, ductility, fibres, hybrid fibre reinforced concrete, MATLAB, Strength

\section{INTRODUCTION}

Concrete is considered a brittle material, primarily because of its low tensile strain capacity and poor fracture toughness. Concrete can be modified to perform in a more ductile form by the addition of randomly distributed discrete fibres in the concrete matrix $^{[1-4]}$.

In Fibre Reinforced Concrete (FRC), fibres can be effective in arresting cracks at both macro and micro levels. For an optimal response, different type of fibres may be suitably combined to produce Hybrid Fibre Reinforced Concrete (HFRC) ${ }^{[5]}$. The use of optimized combinations of two or more types of fibres in the same concrete mixture can produce a composite with better engineering properties than that of individual fibres. This includes combining fibres with different shapes, dimensions, tensile strength and young's modulus to concrete matrices $^{[6]}$.

This research work focuses on the polyolefin-steel hybrid fibre reinforced system. In this system, steel fibre, which is stronger and stiffer, improves the first crack strength and ultimate strength, while the polyolefin fibre, which is more flexible and ductile, leads to improved toughness and strain capacity in the post - cracking zone ${ }^{[7-8]}$. Information available on the ductility performance of hybrid fibre reinforced concrete is still limited. Hence an attempt has been made to study the ductility performance of steel fibre reinforced concrete and hybrid fibre reinforced concrete. An adaptive Neuro-Fuzzy based model has been proposed for predicting the ductility performance characteristics of hybrid fibre reinforced concrete.

The present research investigation is intended to address three major concerns. The first is to explore the possibility of using hybrid fibre system for improved performance of reinforced concrete specimens. The second is to examine the enhancement in flexural capacity of hybrid fibre reinforced concrete specimens. The third is to evaluate the ductility of hybrid fibre reinforced concrete specimens.

\section{MATERIALS AND METHODS}

This study is part of the research program on evaluating the performance of hybrid fibre reinforced concrete. In this paper, ductility properties of steel fibre reinforced and hybrid fibre reinforced concrete are assessed and an adaptive Neuro-Fuzzy based model for predicting the above properties has been proposed.

Specimen Details: $100 \times 100 \times 500 \mathrm{~mm}$ prisms were tested in a loading frame. The test program was designed to study the ductility performance of concrete specimens with and without fibres. Table 1 shows the details of the specimens used for testing.

Corresponding Author: S. Eswari, Department of Civil and Structural Engineering, Annamalai University, Annamalainagar608 002, India 
Table 1: Specimen details

\begin{tabular}{|c|c|c|c|c|}
\hline \multirow{2}{*}{$\begin{array}{l}\text { Sl. } \\
\text { No. }\end{array}$} & \multirow[b]{2}{*}{ Reference code } & \multirow{2}{*}{$\begin{array}{l}\text { Vf, } \\
(\%)\end{array}$} & \multicolumn{2}{|c|}{ Type of fibre } \\
\hline & & & Polyolefin & Steel \\
\hline$\overline{1}$ & H0 - P0 S0 & 0 & 0 & 0 \\
\hline 2 & $\mathrm{H} 0.5$ - P0 S100 & 0.5 & 0 & 100 \\
\hline 3 & H0.5 - P30 S70 & 0.5 & 30 & 70 \\
\hline 4 & H1.0 - P0 S100 & 1.0 & 0 & 100 \\
\hline 5 & $\mathrm{H} 1.0-\mathrm{P} 30 \mathrm{~S} 70$ & 1.0 & 30 & 70 \\
\hline 6 & H1.5 - P0 S100 & 1.5 & 0 & 100 \\
\hline 7 & H1.5 - P30 S70 & 1.5 & 30 & 70 \\
\hline 8 & $\mathrm{H} 2.0-\mathrm{P} 0 \mathrm{~S} 100$ & 2.0 & 0 & 100 \\
\hline 9 & $\mathrm{H} 2.0-\mathrm{P} 30 \mathrm{~S} 70$ & 2.0 & 30 & 70 \\
\hline
\end{tabular}

Note: H0-P0 S0-Plain Concrete

Table 2: Properties of fibres

\begin{tabular}{llll}
\hline S1. & & Fibre details & \\
No. & Fibre properties & Polyolefin & Steel \\
\hline 1 & Length $(\mathrm{mm})$ & 48 & 30 \\
& & Straight & Hooked at ends \\
2 & Shape & $1.22 \times 0.732 \mathrm{~mm}$ & $0.5 \mathrm{~mm}$ \\
3 & Size/Diameter (mm) & 39.34 & 60 \\
4 & Aspect Ratio & 920 & 7850 \\
5 & Density $\left(\mathrm{kg} \mathrm{m}^{-3}\right)$ & $0.90-0.92$ & - \\
6 & Specific Gravity & 6 & 210 \\
7 & Young's Modulus (GPa) & 6 & 532 \\
8 & Tensile strength (MPa) & 550 & \\
\hline
\end{tabular}

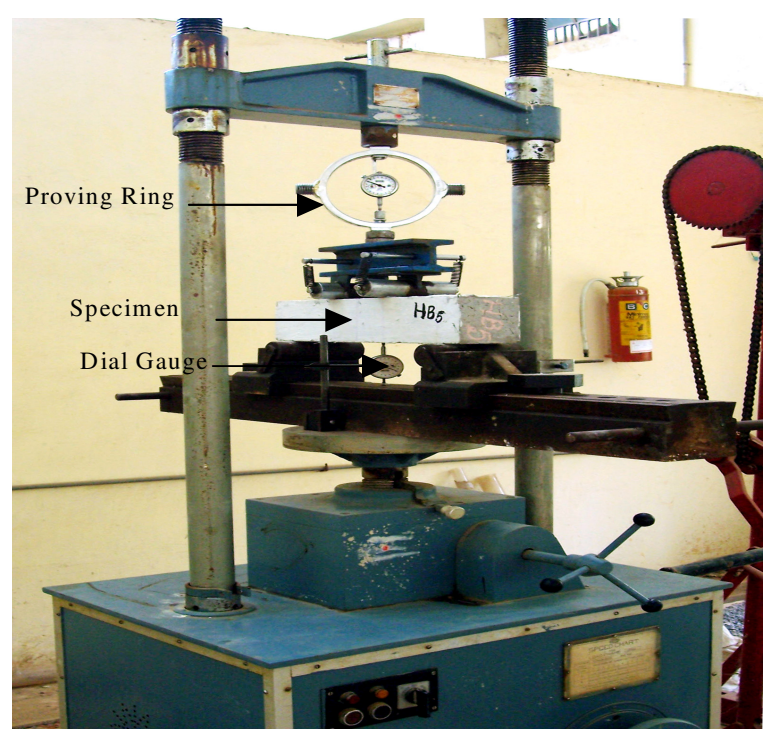

Fig. 1: Flexure test setup

Material Properties: Cement concrete having cube compressive strength of $26.65 \mathrm{MPa}$ was used for casting the specimens. Two types of fibres, nonmetallic polyolefin and steel fibres were used in this investigation. The non-metallic polyolefin fibres were supplied by Elasto-Plastic Concrete (Europe) Ltd. The steel fibres used were Dramix steel fibres (ZC30/0.50) were supplied by Bekaert Fibre Technologies, Belgium. Properties of fibres used in the experimental work are shown in Table 2. For concrete with fibres, superplastizer (High range water reducing admixtureConplast ${ }^{\circledR}$ SP337) was used in appropriate dosage to main the workability of concrete mix.

Testing of Specimens: All the specimens were tested under four point-bending in a loading frame. Deflection measurements were made using dial gauges of $0.01 \mathrm{~mm}$ accuracy. The crack widths were measured using a crack detection microscope with a least count of 0.02 $\mathrm{mm}$. The above measurements were taken at different load levels until failure. The details of test setup are shown in Fig.1.

\section{RESULTS AND DISCUSSION}

The principal test results are presented in Table 3 . The ductility indices of test beams are presented in Table 4. Each value presented is the average of three specimens. A total of 27 specimens were tested in this investigation. It is clear from Table 3, that increasing the fibre content from 0.0 to $2.0 \%$ increases the modulus of rupture. The increase in modulus of rupture was found to be $72.52 \%$ with $2.0 \%$ hybrid fibre content when compared to the plain concrete. The modulus of rupture for beams with and without fibres is shown in Fig. 2. The test results show that the load carrying capacity increases with increase in fibre content. The increase in ultimate load was found to be $72.42 \%$ with $2.0 \%$ hybrid fibre content when compared to that of plain concrete. The ultimate and service loads for beams with and without fibres are shown in Fig. 3-4. From the test results furnished in Table 3, it can be observed that the hybrid fibre reinforced concrete specimens exhibit increase in deflection with increase of fibre content both at service and ultimate loads when compared to the plain concrete. The increase in ultimate and service load deflection was found to be 137.50 and $186.49 \%$ respectively with $2.0 \%$ hybrid fibre content when compared to the plain concrete.

It is evident from Table 3 that the hybrid fibre reinforced concrete specimens exhibit more number of cracks with lesser widths when compared to the plain concrete. The percentage reduction was of the order of $80 \%$ when compared to the plain concrete.

Table 4 indicates that the hybrid fibre reinforced concrete specimens exhibit enhanced ductility than that of plain concrete. It was noticed that for specimens with fibres the failure was not sudden. The randomly oriented fibres crossing the cracked section resisted the propagation of cracks and separation of the section. 
Table 3: Principal test results of specimens in flexure

\begin{tabular}{|c|c|c|c|c|c|c|c|}
\hline S1. No. & $\begin{array}{l}\text { Reference } \\
\text { code }\end{array}$ & $\begin{array}{l}\text { Modulus of } \\
\text { rupture }(\mathrm{MPa})\end{array}$ & $\begin{array}{l}\text { Ultimate } \\
\text { load }(\mathrm{kN})\end{array}$ & $\begin{array}{l}\text { Service } \\
\text { load }(\mathrm{kN})\end{array}$ & $\begin{array}{l}\text { Ultimate deflec- } \\
\text { tion }(\mathrm{mm})\end{array}$ & $\begin{array}{l}\text { Servicedeflec- } \\
\text { tion }(\mathrm{mm})\end{array}$ & $\begin{array}{l}\text { Average } \\
\text { crack width }\end{array}$ \\
\hline 1 & H0-P0 S0 & 7.06 & 17.66 & 11.77 & 0.56 & 0.37 & 0.50 \\
\hline 2 & H0.5-P0 S100 & 7.16 & 17.89 & 11.93 & 0.94 & 0.55 & 0.40 \\
\hline 3 & H0.5-P30 S70 & 9.60 & 24.01 & 16.01 & 0.96 & 0.68 & 0.20 \\
\hline 4 & H1.0-P0 S100 & 10.18 & 25.45 & 16.97 & 1.01 & 0.70 & 0.30 \\
\hline 5 & H1.0-P30 S70 & 11.50 & 28.75 & 19.17 & 1.08 & 0.74 & 0.20 \\
\hline 6 & H1.5-P0 S100 & 10.52 & 26.30 & 17.53 & 1.10 & 0.72 & 0.30 \\
\hline 7 & H1.5-P30 S70 & 11.84 & 29.60 & 19.73 & 1.21 & 0.81 & 0.20 \\
\hline 8 & H2.0-P0 S100 & 11.21 & 28.02 & 18.68 & 1.24 & 0.83 & 0.20 \\
\hline 9 & H2.0-P30 S70 & 12.18 & 30.45 & 20.30 & 1.33 & 1.06 & 0.10 \\
\hline
\end{tabular}

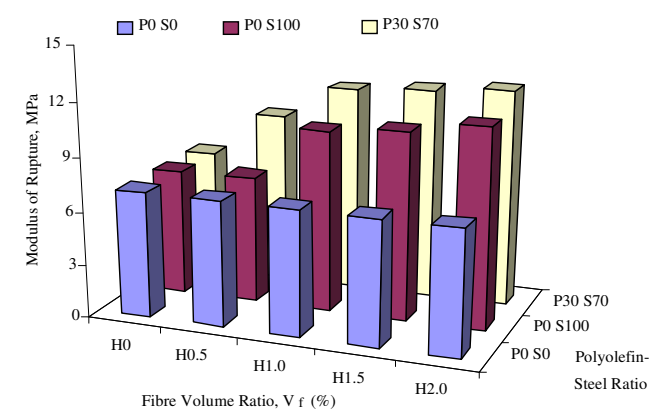

Fig. 2: Modulus of Rupture for Specimens with and without Fibres

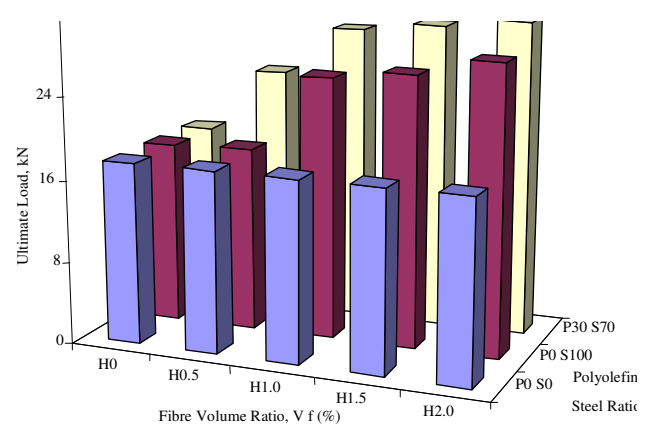

Fig. 3: Ultimate Load for Specimens with and without Fibres

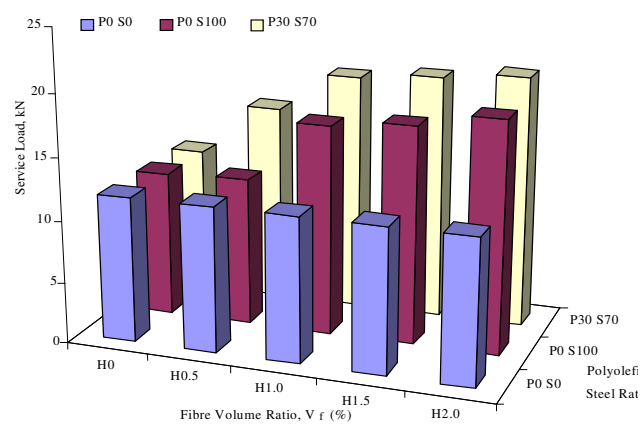

Fig. 4: Service Load for Specimen with and without Fibres

\begin{tabular}{llll}
\multicolumn{5}{l}{ Table 4 Ductility Indices of Test Specimens } \\
\hline Sl. No. & Reference code & Energy ductility & Deflection ductility \\
\hline 1 & H0-P0 S0 & 1.00 & 1.00 \\
2 & H0.5-P0 S100 & 1.25 & 1.18 \\
3 & H0.5-P30 S70 & 1.46 & 1.39 \\
4 & H1.0-P0 S100 & 1.38 & 1.27 \\
5 & H1.0-P30 S70 & 1.51 & 1.48 \\
6 & H1.5-P0 S100 & 1.42 & 1.35 \\
7 & H1.5-P30 S70 & 1.67 & 1.59 \\
8 & H2.0-P0 S100 & 1.59 & 1.46 \\
9 & H2.0-P30 S70 & 1.98 & 1.83 \\
\hline
\end{tabular}

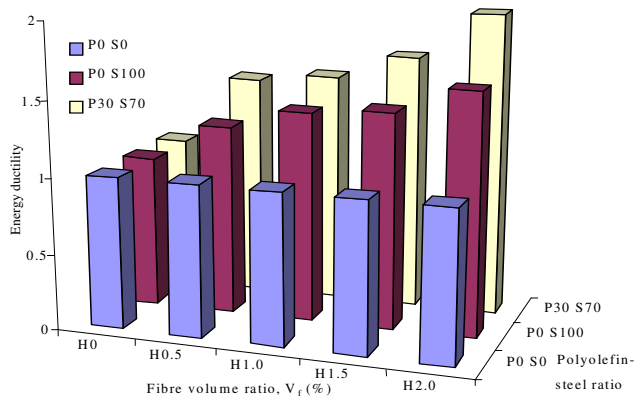

Fig. 5: Energy Ductility for Specimens with and without Fibres

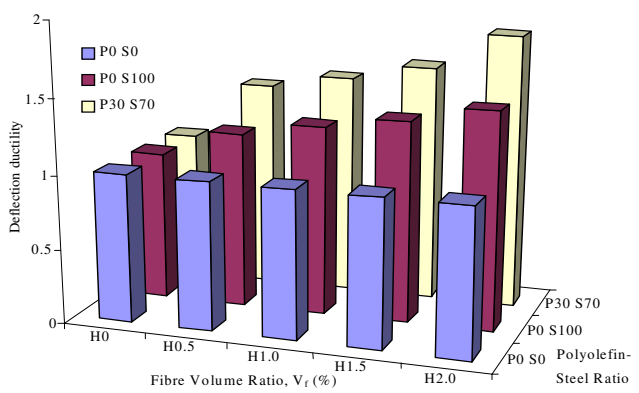

Fig. 6: Deflection ductility for specimens with and without fibres

This caused an increase in the load carrying capacity beyond the first cracking ${ }^{[9-11]}$. The increase in energy and deflection ductility was found to be 98 and $83 \%$ respectively with $2.0 \%$ hybrid fibre content when compared to that of plain concrete. The enhancements 
in energy and deflection ductility for specimens with and without fibres are shown in Fig. 5 and 6.

\section{ADAPTIVE NEURO-FUZZY INFERENCE SYSTEM (ANFIS)}

ANFIS is a hybrid system, which combines the decision-making abilities of fuzzy logic with the computational abilities of neural networks, and offers highly sophisticated platform for modeling/ prediction. Fuzzy is essentially concerned with organizing input data into sets, determination of the membership value (which can be anything from 0 to 1), and taking decision on next action based on a series of rules and moving onto the next state ${ }^{[12]}$.

The Neuro-Fuzzy systems consists of the components of a conventional fuzzy system except that computations at each stage are performed by a layer of hidden neurons and neural network's learning capacity is provided to enhance the system knowledge Fig. 7.

Fuzzification: Fuzzification is the base of the fuzzy system. First, the fuzzy system identifies the input and output of the system. Fuzzification then defines appropriate IF THEN rules and uses raw data to drive a membership function. At this point one is ready to apply fuzzy logic to the system.

Inference: Inference is the operation of applying successive decision-making rules to process the fuzzy input data. As inputs are received by the system, inference evaluates all IF THEN rules and determines their truth-values. If a given input does not precisely correspond to an IF THEN rule, then partial matching of the input data is used to interpolate an answer. Several methods of answer interpolation exist, but lie beyond the scope of this introduction.

Composition: Composition is the operation of combining all fuzzy conclusions obtained by inference into a single conclusion. Different fuzzy rule might have different conclusions, so it is necessary to consider all rules.

Defuzzification: Defuzzification converts the fuzzy value obtained from composition into a crisp valve. This process is often complete since the resulting fuzzy set might not translate directly into a crisp value.

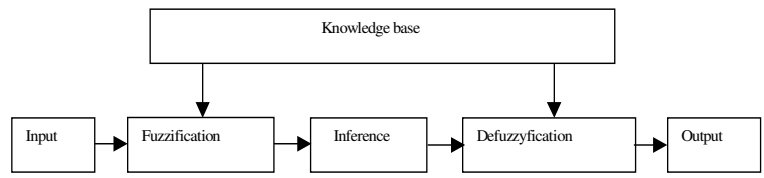

Fig. 7: Schematic diagram of adaptive neuro-fuzzy inference system
Defuzzification is necessary since controllers of physical systems require discrete signals.

\section{DEVELOPING ANFIS BASED PERFORMANCE PREDICTION TOOL}

ANFIS requires generation of individual fuzzy inference system object for each parameter taken up for prediction. Prediction system is developed for Modulus of rupture, ultimate load, ultimate deflection, service load, service load deflection, crack width, energy ductility and deflection ductility. All the fuzzy inference systems take fibre volume fraction, percentage of polyolefin fibre and percentage of steel fibre as input parameters.

The fuzzy inference systems were generated on MATLAB software using fuzzy logic toolbox. The ANFIS models for the above work were developed using anfisedit command available in the fuzzy logic toolbox of Matlab software ${ }^{[13]}$. All parameters required for ANFIS object generation were prepared in the matlab work environment. These parameters were imported to the anfisedit workspace and model generated. The performance of the ANFIS object was tested using data reserved for that purpose. After training and testing, the ANFIS object was exported to matlab workspace and saved in to suitably named disc file. After generating individual fuzzy inference system objects for each prediction parameter, all the ANFIS objects are saved into disk file, in order to make them available for client programs. User interface called hfrc_specimen_properties was also developed to take input from the user, predict the results using appropriate FIS and displaying predicted values. Fig. 8 shows screen shot of the hfrc_specimen_properties. The Root Mean Square Error (RMSE) at the end of training cycle for each of the parameters of prediction is displayed in Table 5. The results predicted by ANFIS along with the percentile errors in prediction are displayed in Table 6.

Table 5: Root mean square error for prediction parameters

\begin{tabular}{lll}
\hline $\begin{array}{l}\text { S1. No. } \\
\text { training data }\end{array}$ & Prediction parameter & RMS error for \\
\hline 1 & Modulus of rupture $(\mathrm{MPa})$ & 0.000614 \\
2 & Ultimate load $(\mathrm{kN})$ & 0.001532 \\
3 & Service load $(\mathrm{kN})$ & 0.001028 \\
4 & Ultimate deflection $(\mathrm{mm})$ & 0.000001 \\
5 & Service load deflection $(\mathrm{mm})$ & 0.000001 \\
6 & Average crack width $(\mathrm{mm})$ & 0.001822 \\
7 & Energy ductility & 0.000001 \\
8 & Deflection ductility & 0.000001 \\
\hline
\end{tabular}


Am. J. Applied Sci., 5 (9): 1257-1262, 2008

\begin{tabular}{lll}
\multicolumn{2}{l}{ Table 6: ANFIS predictions and percentile errors } \\
\hline $\begin{array}{l}\text { S1.No. } \\
\text { for testing data }\end{array}$ & Prediction parameter \\
\hline 1 & Modulus of rupture $(\mathrm{MPa})$ & 21.31 \\
2 & Ultimate load $(\mathrm{kN})$ & 21.32 \\
3 & Service load $(\mathrm{kN})$ & 21.39 \\
4 & Ultimate deflection $(\mathrm{mm})$ & 0.02 \\
5 & Service load deflection $(\mathrm{mm})$ & 26.44 \\
6 & Average crack width $(\mathrm{mm})$ & 17.69 \\
7 & Energy ductility & 13.84 \\
8 & Deflection ductility & 2.74 \\
\hline
\end{tabular}

\section{Command witindow}

'1 - Modulus of Rupture'

12 - Ultimate Load'

'3 - Ultimate Deflection'

' 4 - Service Load'

' 5 - Service Load Deflection'

' 6 - Average Crack Width'

17 - Energy Ductility'

' 8 - Deflection Ductility'

Enter your choice $(1-8): 3$

Enter fibre volume ratio (\%): 1.5

Enter perecentage poly-olefin $(\%): 30$

Enter perecentage steel (\%): 70

Ultimate Deflection: $1.209998 \mathrm{kN}$

Do

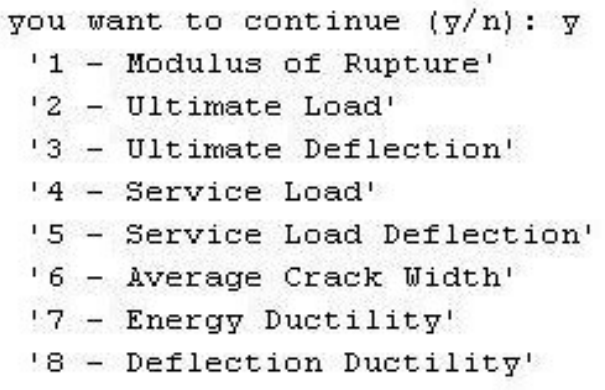

Fig. 8: User Interface for Predicting HFRC Specimen Properties

\section{CONCLUSSION}

A hybrid fibre volume fraction of $2.0 \%$ with $30-70$ Polyolefin-Steel combine significantly improves the ductility performance of reinforced concrete specimens.

The hybrid fibre reinforced concrete specimens exhibit enhanced strength in flexure. The values of modulus of rupture increased up to $72.52 \%$ compared to their plain counterparts.

The hybrid fibre reinforced concrete specimens exhibit increase in deflection to the tune of $186.49 \%$ in comparison with plain concrete.

The hybrid fibre reinforced concrete specimens exhibit reduced crack width at all load levels, the maximum reduction in crack width was found to be $80 \%$ compared to that of plain concrete.

The hybrid fibre reinforcement appreciably enhances the ductility of concrete specimens. The increase in ductility was found to be $98 \%$ and $83 \%$ in terms of energy and deflection respectively.

\section{REFERENCES}

1. ACI Committee 544, 1989. Measurement of Properties of Fibre Reinforced Concrete, (ACI 544.2R-889), American Concrete Institute, Detroit, Michigan, USA.

2. ACI Committee 544, 1982. State-of-the-Report on Fibre Reinforced Concrete, (ACI 544.1R-82), Concrete International: Design and Construction, 4(5): 9-30. American Concrete Institute, Detroit, Michigan, USA.

3. Naaman, A.E. 1985. Fibre Reinforcement for Concretes, Concrete International: Design and Construction, 7(3), 21-25.

4. Singh, S.P., Y. Mohammadi and S.K. Kaushik, 2005. Flexural Fatigue Analysis of Steel Fibrous Concrete Containing Mixed Fibres, ACI Mater. J., 102 (6): 438-444.

5. Banthia, N. and S.M. Soleimani, 2005. Flexural Response of Hybrid Fibre-Reinforced Cementitious Composites, ACI Mater. J., 102 (6): 382-389.

6. Nehdi, M. and J.D. Ladanchuk, 2004. Fiber Synergy in Fiber-Reinforced Self- Consolidating Concrete, ACI Mater. J., 101 (6): 508-517.

7. Banthia, N. and N. Nandakuma, 2003. Crack Growth Resistance of Hybrid Fibre Reinforced Cement Composites, Cement and Concrete Composites, 25: 3-9.

8. Qian, C.X. and P. Stroeven, 2000. Development of Hybrid Polypropylene-Steel Fibre-Reinforced Concrete, Cement and Concrete Res., 30: 63-69. 
9. Bentur, A. and S. Mindness, 1990. Fibre Reinforced Cementitious Composites, Elsevier Applied Science. London.

10. Ramakrishnan, V., 2000. Construction of Highway Structures with Synthetic Structural Fibre Reinforced Concrete, ICFRC, Proceedings of the High Performance Concrete Composites, India 1-17.

11. Shah, S.P., 1987. Strength Evaluation and Failure Mechanisms of Fibre Reinforced Concrete, Proceedings of the International Symposium on Fibre Reinforced Concrete, India, 1-18.
12. Dubois, D. and H. Prade, 1980. Fuzzy Sets and Systems: Theory and Applications, Academic Press, New York.

13. The Math Works, 2002. Fuzzy Logic Toolbox for Use with MATLAB $\AA$, User's Guide (version 2.1.2). 